\title{
Physical and mechanical properties of ceramics from clays of the west of S. Paulo State, Brazil
}

\section{(Propriedades físicas e mecânicas de cerâmicas conformados com argilas do Oeste do Estado de S. Paulo, Brasil)}

\author{
S. R. Teixeira, S. A. de Souza, M. A. L. Nobre \\ Departamento de Física, Química e Biologia, Universidade Estadual Paulista - UNESP \\ C.P. 957, Presidente Prudente, SP, Brazil 19060-900 \\ rainho@prudente.unesp.br
}

\begin{abstract}
Clays and ceramics of interest to the structural ceramic industry were characterized. Some physical properties of ceramic masses formulated from artificial deposits exploited by the local industry were also analyzed. All materials investigated exhibit high contents of fine components $(<2 \mu \mathrm{m})$ and significant plasticity that is compatible with the presence of a great amount of clay minerals. Ceramic probes were prepared by dry pressing and fired at around $855{ }^{\circ} \mathrm{C}$. Flexural strength, linear shrinkage, water absorption, apparent color and weight loss were measured. In addition, the industrial applications of these raw materials were reviewed and newest potential uses proposed.
\end{abstract}

Keywords: clays, ceramic bodies, mechanical properties, strength, plasticity.

Resumo

Argilas de interesse da indústria de cerâmica estrutural foram caracterizadas. Algumas propriedades fisicas de diversas massas cerâmicas, preparadas a partir de material coletado em depósitos artificiais, também foram analisadas. Todas as massas investigadas exibem alta concentração de componentes finos $(<2 \mu \mathrm{m})$ e considerável grau de plasticidade, o que é compativel com a presença de elevado teor de argilominerais. Corpos de prova cerâmicos foram preparados por prensagem a seco e queimados em temperaturas ao redor de $855^{\circ} \mathrm{C}$. Os parâmetros resistência mecânica à flexão, retração linear, absorção de água, cor aparente e perda de peso foram medidos. Como resultado, as aplicações industriais destas matérias primas foram analisadas e revistas, bem como novas aplicações foram propostas.

Palavras-chave: argilas, corpos cerâmicos, propriedades mecânicas, resistência, plasticidade.

\section{INTRODUCTION}

In a recent past, a large number of clayey deposits located on the flood plain nearby the Paranapanema and Paraná rivers were explored. Both rivers are the borderlands between São Paulo and Paraná, as well as Mato Grosso do Sul states corresponding to western region of São Paulo state. These deposits had supplied raw materials to around 150 local structural-ceramic industries being the major industrial plants of small and middle size before the original clayey deposits were flooded by the artificial lake formed by the "Porto Primavera" hydroelectric power plant (1985), located on the Paranapanema River, and the "Rosana" hydroelectric power plant (1998), located on the Paraná River. At present, the industrial raw materials deposits are those composed of mixed clays collected previously by CESP (Companhia Energética de São Paulo S.A.) from original deposits on the flood plains. Before of lake filling up some clays from deposits in the Paraná river area were characterized to determine their physical characteristics and potential as a raw material for structural red ceramic [1]. In addition, several clays extracted from region of the Panorama city, São Paulo state, were also characterized [2].

The structural ceramic industry is an important regional industrial segment consuming about 1.5 million $\mathrm{m}^{3} /$ year of raw material $[1,3]$. Then, it is relevant to study these and other clayey raw materials, which might maintain and/or expand the level of the industrial activity of the region. It is interesting to highlights that as a function of the extraction process from original deposits coordinated by CESP and considering the urgent necessity of creating industrials deposits, several raw materials stemming from distinct areas were mixed together. Then, most of the existing deposits contain two or more distinct raw materials. This has originated a wide range of technical and industrials problems, since the properties of green bodies and ceramics such as, color, mechanical strength, water adsorption, cracks and micro-cracks, lineal contractions during 
drying and firing cycles are affected by both physical and chemical characteristics as average texture and mineralogical composition. As a whole, these recent features have justified the great interest of the academic and industrial areas on the further characterization of these "newest" raw materials stemmed from artificial deposits. Besides these materials some of the samples studied came from flood plains in the neighborhood of some ceramic industries $100 \mathrm{~km}$ away from the CESP deposits.

Samples studied in the present work had several physical parameters such as, mineralogical composition, particle-size distribution and fraction of organic matter, reported in an earlier work [4]. Taking into account the local industry activity, raw materials have been used to produce massive bricks, ceramic blocks and Romana roof tiles. In this work, a deeper insight on the physical and mechanical properties of red ceramics and their correlation with raw materials and some ceramic masses are provided. This aspect is relevant, since these materials have been actually explored by the local ceramic industry. Based on the results, innovative uses for such raw materials are proposed.

\section{MATERIALS AND METHODS}

The clays investigated were collected in the deposits tailored by CESP in regions near the Paraná and Paranapanema Rivers, as previously mentioned. These clays are originated from sedimentary deposits on the flood plains, which are derived from Bauru's sandstone [1].

Eighteen samples were collected (Table I) from specific industrial or environmental deposits ranging five cities of the west region of the São Paulo state: Indiana (4), Martinópolis (1), Panorama (1), Presidente Epitácio (5) and Teodoro Sampaio (7). Seven of them are raw materials and the others are ceramic masses (ceramic pieces not fired). These materials are used by the local industry as follows: 7 for structural bricks, 1 for massive brick, 1 for roof tile, 1 for pottery, 1 for paint pigment in pottery and the others 7 for block and/or massive bricks. Indiana and Martinópolis' samples were collected from industrial deposits, which were constructed from raw materials from several flood plains in the rural region of these cities.

Particle-size analysis (pipet method), amount of organic matter present (Walkley-Black Method) and the mineralogical compositions (X-ray diffraction and glass slide methods) of all samples were determined in a previous investigation [4]. The criteria for differentiation of phyllosilicate species were based on the mineral diagnostic basal $(00 l)$ diffraction maxima of treated samples: $\mathrm{Mg}$ saturated and $\mathrm{Mg}$-glycerol-solvated; $\mathrm{K}$ saturated, K-heated at $300{ }^{\circ} \mathrm{C}$ and $550{ }^{\circ} \mathrm{C}$ [5-8]. These references give further explanations into the preparation of samples for $\mathrm{X}$-ray diffraction and interpretation of X-ray diffraction patterns for samples containing clay minerals.

From each sample, three green bodies $\left(60 \times 20 \times 05 \mathrm{~mm}^{3}\right)$ were uniaxially pressed having each one around $20 \mathrm{~g}$ of

Table I - Origin of the samples.

[Tabela I - Origem das amostras].

\begin{tabular}{cccc}
\hline Sample & City & Samples & Ceramic Industry \\
\hline 01 & Indiana & Clay - "Bairro 7 Copa" & Universo \\
\hline 02 & Indiana & Piece- Water pottery & Indaiá \\
\hline 03 & Indiana & Clay - "Vila Martins" & Universo \\
\hline 04 & Indiana & Yellow Clay (paint) & Indaiá \\
\hline 05 & Martinópolis & Clay - Ceramic Farm & Valentin \\
\hline 06 & Presidente Epitácio & Piece - Massive brick & F. T. \\
\hline 07 & Presidente Epitácio & Clay - Lagoa São Paulo & Alvorada \\
\hline 08 & Presidente Epitácio & Piece - Block & Urubi \\
\hline 09 & Teodoro Sampaio & Clay - Ceramic Deposit & Herling \\
\hline 10 & Teodoro Sampaio & Clay - Ceramic Deposit & São Carlos \\
\hline 11 & Teodoro Sampaio & Piece - Block & St. Cruz \\
\hline 12 & Teodoro Sampaio & Piece - Block & Vera Cruz (Carlos) \\
\hline 13 & Teodoro Sampaio & Clay - Ceramic Deposit & Asa e Casa Branca \\
\hline 14 & Teodoro Sampaio & Piece - Block & Vera Cruz (Francisco) \\
\hline 15 & Teodoro Sampaio & Piece - Block & Vera Cruz (Aloísio) \\
\hline 16 & Presidente Epitácio & Piece - Block & H. Pereira \\
\hline 17 & Presidente Epitácio & Piece - Roof tile & Romana \\
\hline 18 & Panorama & Piece - Block & Milanes \\
\hline
\end{tabular}


material. All green bodies were dried at $110^{\circ} \mathrm{C}$ during 24 hours. In the sequence, ceramics were fired at $855^{\circ} \mathrm{C} \pm 10^{\circ} \mathrm{C}$ during 1 hour, in an electric kiln furnace. The complete thermal cycle was completed in 9 hours. The linear shrinkage and humidity degree were determined via a caliper rule and digital balance with analytical sensitivity, respectively. After firing, the loss of mass, probe color, water absorption, total retraction and flexural strength were assessed on all probes according to $[12,13]$. The results are reported considering the arithmetic average of the measurements for each set of three samples.

\section{RESULTS AND DISCUSSION}

A previous investigation [4] showed that all eighteen samples exhibit high clay fractions, ranging from $38.2 \%$ to $66.3 \%$. Furthermore, the fraction of silt is in the percentage range from $22.2 \%$ to $49.7 \%$, whereas sand is in the range from $3.1 \%$ to $34.1 \%$. As expected, the plasticity degree of the clay is in the range from $20.1 \%$ to $40.7 \%$, being considered as highly plastic with a plasticity limit parameter, PL, higher than $15 \%$. The magnitude of the parameter PL raises an interesting insight on the potential application of these materials. This potential is related to PL values between $17.2 \%$ and $32 \%$, suggesting applications in the red ceramic area. Furthermore, it is important to have in mind that PL values between 26 and 32\% allow ceramic processing and/or conforming via extrusion process [9].

Some properties of the fired ceramic bodies are summarized in Table II. The small values of mass loss $(<14 \%)$ after firing indicate that it is not due to the presence of organic matter at high concentration. Only two of the samples (\#04 and \#07) exhibit water absorption levels higher than $25 \%$. This value is the maximum indicated to industrial applications such as ceramic blocks. Sample \#17 has been used to produce roof tiles having a low level of water absorption (16.6\%). This value is lower than the limit (20\%) suggested for this application [10]. Most of the samples (thirteen) exhibit water absorption smaller than the limit value (Table II) to produce roof tiles, porous plates or floor tiles. As a whole, considering the drying and firing cycles, the total linear shrinkage is smaller than the limit value $(6 \%)$.

The minimum values of flexural strength (FS) indicated to ceramic pieces fired at $900{ }^{\circ} \mathrm{C}$ are: $20 \mathrm{kgf} / \mathrm{cm}^{2}$ to massive bricks, $55 \mathrm{kgf} / \mathrm{cm}^{2}$ to ceramic blocks and $65 \mathrm{kgf} / \mathrm{cm}^{2}$ to roof tiles [11]. Although in this work the samples were fired at $855^{\circ} \mathrm{C}$ during 1 hour, according to Table II, five samples show FS values

Table II - Mass loss, linear shrinkage, water absorption and mechanical physical properties of dried and fired ceramic bodies.

[Tabela II - Perda de massa, retração linear, absorção de água e resistência mecânica àflexão de corpos cerâmicos secos e sinterizados].

\begin{tabular}{|c|c|c|c|c|c|c|c|}
\hline \multirow[t]{2}{*}{ Sample\# } & \multicolumn{2}{|c|}{ Mass Loss } & \multicolumn{2}{|c|}{ Linear Shrinkage } & \multirow{2}{*}{$\begin{array}{c}\text { Water } \\
\text { Absorption (\%) }\end{array}$} & \multicolumn{2}{|c|}{ F. S. } \\
\hline & $110^{\circ} \mathrm{C}$ & $855^{\circ} \mathrm{C}(\%)$ & $110^{\circ} \mathrm{C}$ & $855^{\circ} \mathrm{C}(\%)$ & & & (MPa) \\
\hline 01 & 7.5 & 5.5 & 0.39 & -0.17 & 15.5 & 13.0 & 1.27 \\
\hline 02 & 11.4 & 8.3 & 1.44 & 1.80 & 14.9 & 50.7 & 4.98 \\
\hline 03 & 13.2 & 11.0 & 1.42 & 2.53 & 20.5 & 48.9 & 4.80 \\
\hline $04 *$ & 13.5 & 8.0 & 0.14 & 0.83 & 26.8 & 3.3 & 0.32 \\
\hline 05 & 10.8 & 7.9 & 0.72 & 0.73 & 17.9 & 17.1 & 1.67 \\
\hline 06 & 8.7 & 5.2 & 0.11 & -0.17 & 16.2 & 34.0 & 3.33 \\
\hline 07 & 16.4 & 11.3 & 1.14 & 1.72 & 32.3 & 126.2 & 12.40 \\
\hline 08 & 16.2 & 10.4 & 0.78 & 2.03 & 20.2 & 143.4 & 14.10 \\
\hline 09 & 12.2 & 8.0 & 0.42 & 1.27 & 18.5 & 106.5 & 10.40 \\
\hline 10 & 10.7 & 7.3 & 0.17 & 0.67 & 19.5 & 56.3 & 5.52 \\
\hline 11 & 9.1 & 6.3 & 0.08 & 0.58 & 16.8 & 33.7 & 3.31 \\
\hline 12 & 3.5 & 6.1 & 0.17 & 0.36 & 17.9 & 21.8 & 2.14 \\
\hline 13 & 3.5 & 6.3 & 0.25 & 0.34 & 18.6 & 31.5 & 3.09 \\
\hline 14 & 5.7 & 5.4 & 0.25 & -0.17 & 16.9 & 18.8 & 1.84 \\
\hline 15 & 7.0 & 6.4 & 0.38 & 0.38 & 15.5 & 33.3 & 3.27 \\
\hline 16 & 14.1 & 12.1 & 0.58 & 2.94 & 22.3 & 149.0 & 14.60 \\
\hline 17 & 10.2 & 8.4 & 0.31 & 2.57 & 16.6 & 42.4 & 4.16 \\
\hline 18 & 11.8 & 8.8 & 0.50 & 1.48 & 18.3 & 91.4 & 8.96 \\
\hline
\end{tabular}

* Sample \#04 is a yellow clay (rich in goethite) used to paint pottery. 
higher than $65 \mathrm{kgf} / \mathrm{cm}^{2}$. Six of them have values above $55 \mathrm{kgf} /$ $\mathrm{cm}^{2}$. Eight of them show FS values between 20 and $55 \mathrm{kgf} /$ $\mathrm{cm}^{2}$, including a sample adequate to the production of roof tiles $\left(42.2 \mathrm{kgf} / \mathrm{cm}^{2}\right)$. Only three samples exhibited FS values lower than $20 \mathrm{kgf} / \mathrm{cm}^{2}$. It is interesting to note that the FS limit value to roof tiles $\left(65 \mathrm{kgf} / \mathrm{cm}^{2}\right)$ is reached when the ceramic bodies are fired at temperatures $\geq 950{ }^{\circ} \mathrm{C}$. This behavior is in accordance with previous work [10]. Samples \#07, \#08, \#09, \#16 have very high FS values (from 106.5 to $149.0 \mathrm{kgf} / \mathrm{cm}^{2}$ ) that indicate further application to production of ceramic plates. In Table III samples are classified according to their flexural strength and water absorption.

Fig. 1 shows that besides the clay concentration a low sand concentration is a determining factor to obtain ceramics with high flexural strength. Also, it can be observed that in general samples from the Paraná River margins (P. Epitácio and Panorama) result in ceramics with highest FS. Furthermore, it has been taken into account that different mineral compositions between samples collected in different places influence their final properties. As an example, sample \#03 has low sand and high clay concentrations, but its flexural strength is smaller than samples \#08 or \#18. Sample \#04 present very low flexural strength due to their very high iron oxides concentration.

All samples have kaolinite (major phase), mica and 2:1 layered clay minerals, according to a previous work [4]. Some of them were identified as being smectite with variable concentrations leading to distinct degree of heterogeneous shrinkage. Thus, differential shrinkage is exerted on the ceramic body after dry process. As a consequence, a high level of cracks and microcracks can be generated. As expected, these cracks and porosity (due to organic matter) might contribute to the lowest FS values measured. The development of cracks is further correlated with asymmetric shrinkage of ceramic bodies. It seems that the origin of this phenomenon can be assigned twofold. First, a heterogeneous mixture of clays is highlighted. Second, according to previous work [12], the flexural strength is a function of the particle size distribution and clay composition. In particular, the value of rupture tensile increases with decreasing of the average particle size. Taking into account the clays investigated and based on X-ray diffraction data published elsewhere [4], the kaolinite is the major clay mineral present in

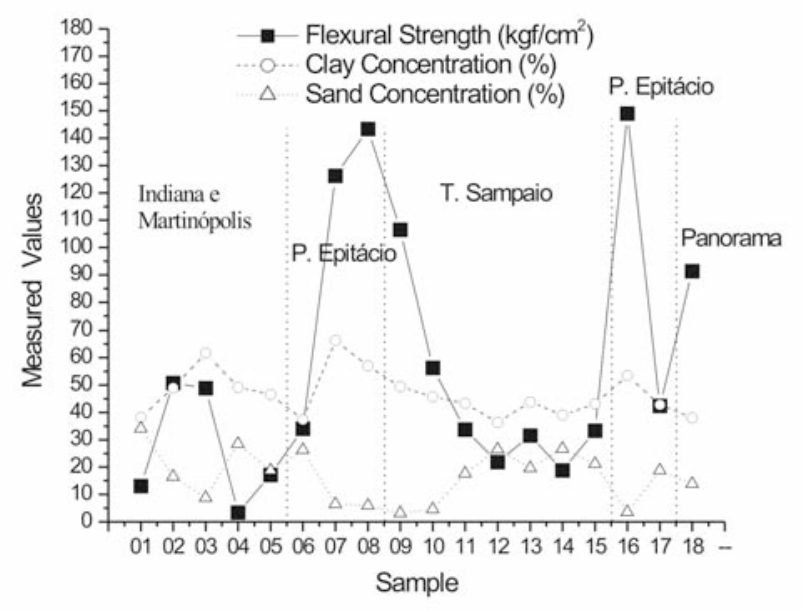

Figure 1: Flexural strength and clay and sand concentrations of the samples.

[Figura 1: Resistência mecânica à flexão e concentrações de argila e areia das amostras].

all samples with different fractions and crystallization degree. The presence of illites in the clay suggests some influence on the mechanical behavior of the samples investigated. In this sense, the fine quartz fraction observed in all samples might also exert some influence on the samples properties (increase FS and reduce shrinkage) after firing.

It is known [12] that pure clay minerals show a wide range of flexural strength (FS) as follows: 0.7 to $49 \mathrm{kgf} / \mathrm{cm}^{2}$ to kaolinite, 14 to $70 \mathrm{kgf} / \mathrm{cm}^{2}$ to illites and 21 to $56 \mathrm{kgf} / \mathrm{cm}^{2}$ to smectites. These values can be classified as: low $\left(0\right.$ to $\left.7 \mathrm{kgf} / \mathrm{cm}^{2}\right)$, lower intermediate ( 7 to $\left.14 \mathrm{kgf} / \mathrm{cm}^{2}\right)$, middle intermediate (14 to $\left.28 \mathrm{kgf} / \mathrm{cm}^{2}\right)$, upper intermediate $\left(28\right.$ to $\left.56 \mathrm{kgf} / \mathrm{cm}^{2}\right)$ and high (at above $56 \mathrm{kgf} / \mathrm{cm}^{2}$ ). Based on the above benchmarks, the samples can be classified (Table IV) having in mind that low FS values disqualify the raw material for ceramic uses. According to Table IV, only sample \#04 (rich in goethite) cannot be used to produce ceramic products, because of low FS values; one sample has lower intermediate value; three samples exhibit middle to intermediate values. Fortunately,

Table III - Sample classification according to flexural strength and water absorption.

[Tabela III - Classificação de cada amostra de acordo com sua resistência mecânica e absorção de água].

\begin{tabular}{|c|c|c|c|c|}
\hline \multirow[t]{2}{*}{ Ceramic Piece } & \multicolumn{2}{|c|}{ Flexural Strength $\left(\mathrm{kgf} / \mathrm{cm}^{2}\right)$} & \multicolumn{2}{|c|}{ Water Absorption(\%) } \\
\hline & Indicated Values* & Samples \# & Indicated Values* & Samples \# \\
\hline Not classified & $<20$ & $01,04,05$, and 14 & $\longrightarrow$ & 04 \\
\hline Massive bricks & $\geq 20$ & $02,03,06,11,12,13,15$ and 17 & 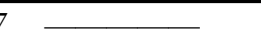 & 07 \\
\hline$\overline{\text { Ceramic blocks }}$ & $\geq 55$ & 10 & $\leq 25$ & 03,08 and 16 \\
\hline Roof tiles & $\geq 65$ & $07,08,09,16$ and 18 & $\leq 20$ & $\begin{array}{c}01,02,05,06,09 \text { to } 15 \\
17 \text { and } 18\end{array}$ \\
\hline
\end{tabular}

* Indicated values [10,12]. 
Table IV - Samples Classification according to flexural strength (FS). [Tabela IV - Classificação das amostras de acordo com sua resistência mecânica FS].

\begin{tabular}{cc}
\hline Classification of FS* & Sample \# \\
\hline Low & 04 \\
\hline Lower Intermediate & 01 \\
\hline Middle & $05-12-14$ \\
\hline Upper Intermediate & $02-03-06-10-11-13-15-17$ \\
\hline High & $07-08-09-16-18$ \\
\hline
\end{tabular}

* FS classification [12].

most of the samples have upper intermediate values (eight of them) or high values (five of them). It is interesting to point out that, despite the high fraction of kaolinite at all clays, a great number of FS values listed on Table IV are higher than one reported to pure kaolinite $\left(0.7\right.$ to $\left.49 \mathrm{kgf} / \mathrm{cm}^{2}\right)$. These values indicate the influence of other clay minerals on FS values and other physical parameters. In order to improve the comprehension of the ceramic properties investigated here, further firing tests at different temperatures $\left(\geq 855^{\circ} \mathrm{C}\right)$ are required, along with some tests using powders with different particle size distributions. The results of these tests can determine the kind of innovative product in terms of superior application that can be produced from each raw material. Some samples will undoubtedly have their ceramic properties improved by milling the raw material to obtain powders with small particle size and sintering the probes in higher temperatures than those used in this work.

All raw samples exhibit two major colors as observed in a previous work [4]. The first set is gray and its tonality changes from weak to intense, while the second one shows a brownish color with tonality changing between soft and hard intensity, after drying at $110{ }^{\circ} \mathrm{C}$. Ceramics exchange their colors after firing. The brownish bodies exhibit a typical red color after firing at $855{ }^{\circ} \mathrm{C}$, such as samples \#08, \#17 and \#18. Furthermore, some of the samples exchange its colors from black to pale brown suggesting other potential applications as ceramic products. As a matter of fact, sample's color changes to light brown (10YR8/3), \#3, to light red (10YR6/6) samples $\# 08$, \#17 and \#18, according to Munsell's chart [14] used to classify the color of soils. Sample \#04 is red (2.5YR5/8) due to the transformation of goethite to hematite after firing. Other samples have several colors ranging from brownish to yellowish and were not classified. As a whole, samples exhibit light or pale colors after firing, including samples \#01, \#02, $\# 03, \# 05$ and \#06. They could be used to produce other products with final prices higher than red ceramics, including light brown or yellowish roof tiles or floor tiles.

\section{CONCLUSIONS}

This study leads us to the following conclusions:

1. The results of the physical characterization showed that after firing the samples present: low mass loss, low water absorption, good linear retraction and flexural strength, having technological features to produce a wide range of red ceramics.

2. After firing, some raw materials depicted light colors or were nearly white, suggesting a possible use to produce materials with superior commercial value, when compared to structural blocks and massive bricks.

3. Some of them have excellent properties (light colors or very high flexural strength) and could be used to produce different kinds of structural ceramics.

\section{AKNOWLEDGMENTS}

The authors gratefully acknowledge the partial support of this work granted by FUNDUNESP and FAPESP, as well as CNPq for the students' scholarships and to Laboratório de Engenharia Civil - UNESP/FEIS.

\section{REFERENCES}

[1] CESP - Companhia Energética do Estado de São Paulo, Reservatório de Porto Primavera: Estudo e Relatório de Impacto Ambiental - EIA/RIMA, vol. I e II (1992/93).

[2] J. J. Almeida, R. C. Valério, E. R. Ninelo, S. R. Teixiera e W. A. Carvalho, "Mineralogia da Fração Argila de Materiais Usados na Produção de Tijolos e Telhas na Região de Panorama - SP", 47a Reunião Anual da SBPC, São Luis MA, 09 a 14 de julho (1995).

[3] J. F. M. Motta, M. Cabral Jr., L. C. Tanno, Z. Hellmeister Jr., A. Zandonadi, S. Saka e N. H. Saito, "Caracterização de argilas do vale do Rio Paraná (SP e MS), visando à aplicação nas industrias de cerâmica vermelha", Anais do $39^{\circ}$ Congresso Brasileiro de Cerâmica, Águas de Lindóia - SP, 10 a 13 de junho (1995) 401.

[4] S. R. Teixeira, S. A. Souza e C. A. I. Moura, "Mineralogical characterization of clays used in the structural ceramic industry in west of S. Paulo State, Brazil", Cerâmica 47, 304 (2001) 204.

[5] A. Klute (Editor), Methods of Soil Analysis: Physical and Mineralogical Methods, Madison, SSSA Book Series: 5, Second Edition (1986).

[6] J. B. Dixon, G. N. White, Soil Mineralogy Laboratory Manual: Agronomy 626, Texas A \& M University (1997).

[7] J. B. Dixon, D. G. Schulze, Soil Mineralogy with Environmental Applications, Madison, SSSA Book Series: 7 (2002).

[8] A. P. F. Albers, F. G. Melchiades, R. Machado, J. B. Balbo, A. O. Boschi, Cerâmica 48, 305 (2002) 34-37.

[9] I. S. S. Santos, N. I. W. Silva, H. J. Wildner, M. Boff, Anais do $39^{\circ}$ Congresso Brasileiro de Cerâmica, Águas de Lindóia - SP (1995) 401.

[10] C. M. F. Vieira, J. N. F. de Holanda, D. G. Pinatti, "Estudo de massa cerâmica vermelha", Cerâmica 46, 297 (2000) 14.

[11] R. S. Macedo, A. G. S. Galdino, C. R. S. Morais, H. C. Ferreira, "Estudo preliminar de argilas do estado da Paraíba para utilização como matéria-prima em cerâmica vermelha Parte I", Cerâmica 42, 275 (1996) 259. 
[12] P. de S. Santos, Ciência e Tecnologia de Argilas, vol. 1, de Ivinhema/MS”, Dissertação de Mestrado, UFMS-MS (2002). Ed. Edgard Blücher Ltda, S. Paulo (1989).

[14] Munsell Soil Color Charts, Munsell Color Company, Inc., [13]A. A. Zanfolim, "Caracterização e propriedades físicas da argila Baltimore, Maryland, USA (1954).

(Rec. 23/07/03, Rev. 17/05/04, Ac. 25/05/04) 